Jurnal Media Pertanian Vol. 1 No. 2 Tahun 2016 Hal. 69 - 77

Media Komunikasi Hasil Penelitian dan Review Literatur Bidang Ilmu Agronomi

ISSN $2503-1279$

\title{
TUMPANGSARI TANAMAN KELAPA SAWIT (Elaeis guineensis Jacq.) dengan TANAMAN KARET (Hevea brassiliensis L.)
}

\author{
Yulistiati Nengsih \\ Program Studi Agroteknologi, Fakultas Pertanian Universitas Batanghari \\ Jl. Slamet Riyadi-Broni, Jambi 36122 Telp. +62074160103 \\ email : nyulistiati@yahoo.com
}

\begin{abstract}
Monoculture cultivation system has impact on various biotic surrounding in it. Palm oil cultivation with intercropping system started to be popular to avoid environment damaged. Intercropping cultivation between palm oil and other plant was possible in existing both intraspecific and interspecific competation. Various form of this competation was needed to be learned. The compatible variables to measure these competation forms is Land Equal Ratio (LER) that able to compare the benefit between monoculture and multicultural cultivation system. The aim of this research was to determine the LER of multicultural cultivation between palm oli and rubber tree. this research had been held in February - July 2016 at Wanareja Village, Rimbo Ulu Sub-District, Tebo Regency. Survey method was use in this research, and the location above was purposely sampled suitable with the needed data. In the other word one reason of this location to be sampled was the only area that showed the existing of multicultural cultivation system especially between palm oil and rubber tree. There were several farmer characteristics to be sampled as a respondent e.g. : 1). Farmers that has no cooperation with enterprise ; 2). The farmer has at least one hectare of land; and 3). Show plant at the minimally age of 5 years. The result of this research showed that the production of Monoculture cultivation was higher than multicultural cultivation system, but it had 1.5 of LER so it indicated that the multicultural cultivation system give 50\% higher benefit than Monoculture cultivation system.
\end{abstract}

keywords: Monoculture, multicultural, Intercropping

\begin{abstract}
Abstrak
Pertanaman monokultur diyakini akan berdampak terhadap keragaman makhluk hidup yang berada pada areal tersebut. Wacana untuk membudidayakan sawit dengan sistem polikultur mulai mencuat seiring dengan kekhawatiran terjadinya kerusakan lingkungan. Budidaya polikultur antara tanaman sawit dengan tanaman lain memungkinkan terjadinya persaingan intra dan interspesifik. Perlu kajian untuk mengetahui bentuk dari persaingan tersebut. Peubah yang paling menentukan yang dapat diukur dari bentuk persaingan tersebut adalah Nisbah Kesetarahan Lahan (NKL) yang akan mengkaji keuntungan budidaya secara monokultur atau polikultur. Penelitian ini bertujuan untuk menentukan nilai nisbah kesetaraan lahan (NKL) pada tanaman polikultur kelapa sawit dengan tanaman karet. Penelitian telah dilaksanakan pada Bulan Pebruari sampai Juli 2016 di Desa Wanareja Kecamatan Rimbo Ulu Kabupaten Tebo. Penelitian menggunakan metode survey. Dalam hal ini pemilihan Kabupaten dan Desa dilakukan dengan sengaja ditentukan sesuai dengan kebutuhan data. Di Desa Wanareja Kecamatan Rimbo Ulu Kabupaten Tebo terdapat tanaman kelapa sawit polikultur dengan tanaman karet, maka petani dari desa ini yang dijadikan sampel. Adapun syarat-syarat petani yang akan dijadikan sampel adalah : 1) Petani yang tidak berkolaborasi dengan perusahaan, 2) luas lahan minimal satu hektar, dan 3) Umur tanaman minimal 5 tahun. Hasil penelitian menunjukkan produksi tanaman kelapa sawit sistem monokultur lebih tinggi dari sistem polikultur. Namun berdasarkan rata-rata produktivitas lahan perhitungan nilai nisbah kesetaraan lahan (NKL) menunjukkan nilai 1,5 ini menggambarkan bahwa pertanaman tumpangsari
\end{abstract}


Jurnal Media Pertanian Vol. 1 No. 2 Tahun 2016 Hal. 69 - 77

Media Komunikasi Hasil Penelitian dan Review Literatur Bidang Ilmu Agronomi

ISSN $2503-1279$

(polikultur) dari segi ekonomi lebih menguntungkan setengah atau 50\% dari tanaman sistem monokultur.

Kata Kunci : Monokultur, Polikultur, tumpangsari

\section{PENDAHULUAN}

Kelapa sawit merupakan salah satu komoditi sub sektor perkebunan yang memberikan andil besar dalam pemasukan devisa di luar sektor minyak dan gas bumi. Komoditi ini juga menyerap tenaga kerja yang cukup besar dan mampu memberikan kemakmuran bagi masyarakat yang mengusahakannya (Risza, 1994).

Setyamidjaja (2006), menyatakan bahwa tanaman kelapa sawit merupakan sumber penghasil minyak nabati yang digunakan secara luas dalam berbagai industri. Risza (1994) juga menjelaskan bahwa disamping digunakan sebagai bahan baku industri pangan, kelapa sawit dapat digunakan sebagai bahan baku industri non pangan.

Tanaman kelapa sawit termasuk tanaman multiguna. Tanaman tersebut mulai banyak menggantikan posisi penanaman komoditas perkebunan lain, yaitu tanaman karet. Tanaman kelapa sawit kini tersebar di berbagai daerah. Secara umum dapat diindikasikan bahwa pengembangan perkebunan kelapa sawit masih mempunyai prospek harga, ekspor, dan pengembangan produk (Suwarto dan Octavianty, 2010).

Berdasarkan data Direktur Jenderal Perkebunan Kementerian Pertanian pada tahun 2014 luas areal perkebunan kelapa sawit di Provinsi Jambi 688.810 dengan produksi 1.857.260. tanaman kelapa sawit saat ini tersebar di hampir seluruh provinsi di Indonesia. Provinsi Riau dengan luas areal 2,30 juta Ha merupakan provinsi yang mempunyai perkebunan kelapa sawit terluas disusul berturut-turut Provinsi Sumatera Utara seluas 1,39 juta Ha, Provinsi Kalimantan Tengah seluas 1,16 juta $\mathrm{Ha}$ dan Sumatera Selatan dengan luas 1,11 juta Ha serta provinsi-provinsi lainnya (Dirjen perkebunan, 2014).

Berdasarkan data Statitik Perkebunan Provinsi Jambi pada tahun 2012 luas areal, produksi dan produktivitas kelapa sawit pada tiap kabupaten di provinsi Jambi dapat dilihat pada Tabel 1.

Tabel. 1. Luas, Produksi dan Produktivitas Tanaman Perkebunan Provinsi Jambi Menurut Kabupaten pada tahun 2012

\begin{tabular}{lccc}
\hline \multicolumn{1}{c}{ Kabupaten } & $\begin{array}{c}\text { Luas Areal } \\
\text { (Ha) }\end{array}$ & $\begin{array}{c}\text { Produksi } \\
\text { (Ton) }\end{array}$ & $\begin{array}{c}\text { Produktivitas } \\
\text { (Kg/Ha) }\end{array}$ \\
\hline Batanghari & 84.345 & 205.299 & 3.300 \\
Muaro Jambi & 130.766 & 341.104 & 3.136 \\
Bungo & 85.726 & 151.974 & 3.616 \\
Tebo & 48.383 & 139.136 & 4.084 \\
Merangin & 52.748 & 173.553 & 3.856 \\
Sarolangun & 48.136 & 127.472 & 3.410 \\
Tanjung Jabung Barat & 105.891 & 283.131 & 3.377 \\
Tanjung Jabung Timur & 33.251 & 41.171 & 2.377 \\
Kerinci & 94 & 12 & 1.333 \\
Kota Sungai Penuh & & & - \\
Jumlah/Total & 589.340 & 1.472 .852 & 3.398 \\
Sumber : Dinas Perkebunan Provinsi Jambi 2012 & &
\end{tabular}


Jurnal Media Pertanian Vol. 1 No. 2 Tahun 2016 Hal. 69 - 77

Media Komunikasi Hasil Penelitian dan Review Literatur Bidang Ilmu Agronomi ISSN $2503-1279$

Isu mengenai dampak terhadap lingkungan hidup yang ditimbulkan dari pembukaan lahan menjadi perkebunan kelapa sawit saat ini, sangat gencar didengungkan oleh para pemerhati lingkungan. Oleh sebab itu, dalam pembangunan perkebunan kelapa sawit, selain mengejar target yang telah ditentukan oleh perusahaan, kita juga harus memperhatikan lingkungan hidup sehingga ekosistem tidak terganggu. Dampak negatif terhadap lingkungan menjadi bertambah serius karena dalam prakteknya pembangunan perkebunan kelapa sawit tidak hanya terjadi pada kawasan hutan konversi, melainkan juga konservasi yang memiliki ekosistem yang unik dan mempunyai nilai keanekaragaman hayati yang tinggi (Manurung, 2000; Potter and Lee, 1998).

Saat ini telah ada anjuran untuk membudidayakan kelapa sawit dengan mengkombinasikan dengan tanaman multi purpose tree species (MPTS) yaitu tanaman multi guna. Maksudnya, tanaman ini dapat menghasilkan, daun, kayu, buah dan juga menguntungkan bagi masyarakat. Tanaman kombinasi tersebut dapat berupa tanaman pangan, tanaman perkebunan atau tanaman MPTS, (Distanhutbun, 2011).

Kombinasi tanaman kelapa sawit dengan tanaman lain (interspesifik) masih belum dapat ditentukan apakah bersifat independent (tanaman tidak saling mempengaruhi), kompetitif (kenaikan hasil spesies tanaman yang satu mengakibatkan penurunan hasil lain), alelopati (terjadi akibat seksresi/ekskresi/zat toksik yang dikeluarkan oleh jenis tanaman tertentu dalam suatu komoditas) atau stimulasi (produktivitas suatu tanaman akan ditingkatkan akibat keberadaan suatu spesies lain). Sifat-sifat kombinasi ini dapat ditentukan dari pengamatan lapangan berdasarkan pertumbuhan dan atau produksi tanaman. Tanaman sela diantara pertanaman kelapa sawit adalah mengusahakan tanaman pangan, perkebunan dan hortikultura sebagai tanaman sela di antara kelapa sawit sangat berpeluang untuk dilakukan. Jenis tanaman sela dan bentuk usaha taninya tergantung sumber daya yang tersedia dan permintaan pasar. Sumber daya yang dimaksud berupa kondisi lahan dan iklim, kondisi tanaman kelapa sawit, dan status teknologi, sedang bentuk usaha taninya ditentukan oleh sosial budaya dan ekonomi petani, serta permintaan pasar (Edi dan Zainal, 2003).

Tumpangsari kelapa sawit memiliki beberapa kelebihan yaitu: mengoptimalkan pemanfaatan lahan yang ditujukan oleh nisbah kesetaraan lahan (NKL) atau land equivalent ratio (LER), menghasilkan produk yang beragam, memperoleh hasil tambahan, memperbaiki kesuburan tanah dan mencegah erosi (Balai Pengkajian Teknologi Pertanian, 2012).

Hasil pengamatan pendahuluan diketahui bahwa telah dilakukan kombinasi antara kelapa sawit dengan tanaman karet (tanaman perkebunan). Sampai sejauh mana model kombinasi tanaman kelapa sawit dengan tanaman lain ini bersifat menguntungkan atau tidak masih memerlukan pengamatan lebih lanjut.

Beberapa pendapat menyatakan tanaman pendamping tidak tumbuh dengan baik dan produksi kelapa sawit menurun kalau kombinasi ini dilakukan. Pendapat ini memerlukan pembuktian berupa data lapangan untuk membuktikan kebenaran pendapat tersebut. Pendapat ini memerlukan adanya pengamatan yang intensif dalam bentuk sebuah penelitian yang berjudul "Polikultur Tanaman Kelapa Sawit (Elaeis guineensis Jacq.) dengan Tanaman Karet (Havea brassilienis Mull)". 
Jurnal Media Pertanian Vol. 1 No. 2 Tahun 2016 Hal. 69 - 77

Media Komunikasi Hasil Penelitian dan Review Literatur Bidang Ilmu Agronomi

ISSN $2503-1279$

\section{Tempat dan Waktu Penelitian.}

\section{METODE PENELITIAN}

Penelitian ini dilakukan di Desa Wanareja Kecamatan Rimbo Ulu Kabupaten Tebo. Penelitian ini dilakukan pada bulan April - Juli 2016.

\section{Bahan dan Alat}

Bahan yang digunakan dalam penelitian ini adalah pertanaman kelapa sawit yang dikombinasikan dengan karet. Alat yang digunakan dalam penelitian ini meliputi GPS, meteran, timbangan, lembar kuisioner dan alat perekam.

\section{Rancangan Percobaan}

Penelitian ini menggunakan metode survey pada lahan-lahan petani yang ditanami dengan kelapa sawit monokultur dan kelapa sawit dikombinasikan dengan karet. Lokasi yang dipilih dalam penelitian ini dilakukan dengan sengaja dimana lokasi-lokasi tersebut terdapat budidaya kombinasi kelapa sawit dengan karet lokasilokasi tersebut seperti yang ditunjukan pada bagan dibawah ini :

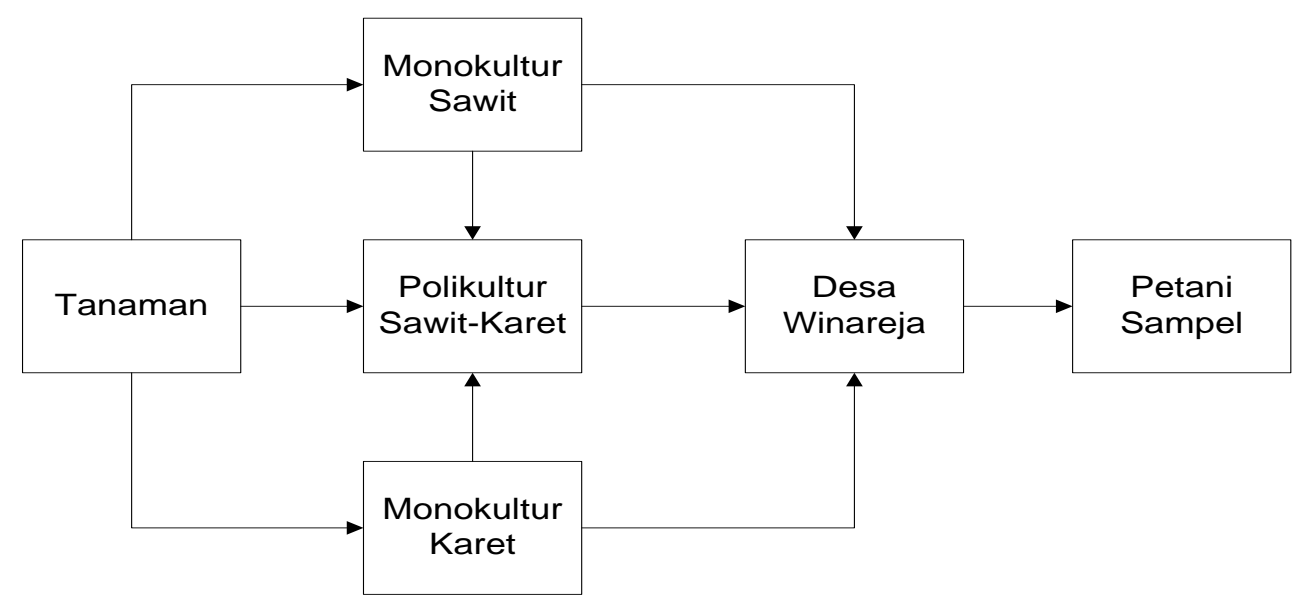

Gambar1 : Bagan lokasi penelitian dan petani sampel

Metode pengambilan sampel menggunakan metode SRS (simple random sampling) dimana jumlah populasi tanaman lebih dari 100 maka tanaman sampel sebanyak $15 \%$ sedangkan populasi tanaman kurang dari 100 maka tanaman sampel sebanyak 50\% (Tasri, 2007). Tanaman sampel dipilih secara sengaja, tanaman yang dijadikan sampel dilihat titik koordinat dengan menggunakan GPS.

\section{Parameter yang Diamati}

Jarak Tanam (m)

Model posisi tanam dan jarak tanam diukur pada saat penelitian dengan mengukur jarak kelapa sawit dengan tanaman karet. Jarak tanam akan diukur dengan cara mengukur antar pokok tanaman menggunakan meteran.

Tinggi Tanaman (m)

Pengukuran tinggi tanaman kelapa sawit dan karet dilakukan di lapangan dengan menggunakan meteran. Dengan cara mengukur tinggi batang dari pangkal batang sampai ke tajuk.

Lingkar batang $(\mathrm{cm})$

Pengukuran lingkaran batang kelapa sawit dan karet dilakukan di lapangan dengan menggunakan meteran. Dengan cara mengambil rata-rata lingkar pangkal batang.

Umur Mulai produksi 
Jurnal Media Pertanian Vol. 1 No. 2 Tahun 2016 Hal. 69 - 77

Media Komunikasi Hasil Penelitian dan Review Literatur Bidang Ilmu Agronomi ISSN $2503-1279$

Untuk mengetahui umur tanaman mulai berbuah maka dilakukan wawancara terhadap petani kelapa sawit dan karet.

Produksi TBS Kelapa Sawit dan Karet Kombinasi (ton/ha)

Pengamatan produksi TBS yang dihasilkan kelapa sawit dan karet pada lahan yang ditumpangsarikan dilakukan wawancara dengan petani.

Produksi TBS Kelapa Sawit dan Karet Tunggal (ton/ha)

Pengamatan produksi karet dan kelapa sawit pada lahan yang ditanam secara monokultur dilakukan wawancara dengan petani.

Produktivitas lahan

Untuk mengetahui produktivitas lahan pada penanaman tumpangsari dapat juga dihitung dengan menggunakan Nisbah Kesetaraan Lahan (NKL) atau Land Equivalent Ratio (LER).

$N K L=\frac{X c}{X o}+\frac{Y c}{Y o}$

NKL $=$ Nisbah Kesetaraan Lahan

$\mathrm{Xc} \quad=$ Produksi Sawit pada Pertanaman Tumpangsari $(\mathrm{Kg})$

Xo = Produksi Kelapa Sawit pada Pertanaman Tunggal Kelapa Sawit $(\mathrm{Kg})$

Yc $\quad=$ Produksi Karet pada Pertanaman Tumpangsari $(\mathrm{Kg})$

Yo $\quad=$ Produksi Karet pada Pertanaman Tunggal Karet $(\mathrm{Kg})$

\section{Analisis Data}

Guna menjawab hipotesis yang diajukan, data-data yang diperoleh di lapangan dilakukan analisis statistika dengan metode deskriptif. Metode deskripsi dalam bentuk tabulasi.

\section{HASIL DAN PEMBAHASAN}

Penelitian ini dilakukan dengan survey terhadap dua petani yang terletak di satu desa yang memiliki kebun dengan tanaman kelapa sawit dan tanaman karet sistem monokultur dan polikultur. Ada pun titik koordinat lokasi pada masing-masing petani sampel dapat dilihat pada Tabel 8 .

Tabel 8. Lokasi-lokasi sampel petani di Wanareja

\begin{tabular}{l|l|l}
\hline Nama desa & Sampel & Titik koordinat \\
\hline \multirow{3}{*}{ Wanareja } & Ps1 & $\mathrm{S}=0106^{\prime} 15,30^{\prime \prime}$ \\
& & $\mathrm{E}=10203^{\prime} 20,64^{\prime \prime}$ \\
& Ps2 & $\mathrm{S}=0106^{\prime} 15,00^{\prime \prime}$ \\
& & $\mathrm{E}=10203^{\prime} 22,15^{\prime \prime}$ \\
& Ps3 & $\mathrm{S}=0107^{\prime} 06,12^{\prime \prime}$ \\
& $\mathrm{E}=10203^{\prime} 22,05^{\prime \prime}$ \\
\hline
\end{tabular}

Dari Tabel 8, dapat dilihat terdapat perbedaan titik koordinat disetiap lokasi sampel petani. Pengambilan titik koordinat menggunakan GPS di tengah lokasi pengambilan sampel dan setiap perbedaan satu menit titik koordinat sama dengan jaraknya 30 meter. 
Jurnal Media Pertanian Vol. 1 No. 2 Tahun 2016 Hal. 69 - 77

Media Komunikasi Hasil Penelitian dan Review Literatur Bidang Ilmu Agronomi ISSN $2503-1279$

\section{Jarak Tanam (cm)}

Dari hasil pengukuran jarak tanam antar pokok tanaman untuk kombinasi tanaman kelapa sawit dengan karet, dilakukan dengan cara mengukur jarak tanam kelapa sawit antar kelapa sawit dan karet antar karet pada setiap sampel tanaman. Pada penanaman kelapa sawit dan karet tunggal jarak tanam di ukur antar tanaman pokok pada setiap sampel tanaman. Hasil pengukuran jarak tanam dapat dilihat pada Tabel 2.

Tabel 2. Jarak tanam kelapa sawit dan karet pada sistem monokultur dan sistem polikultur

\begin{tabular}{|c|c|c|c|}
\hline \multicolumn{4}{|c|}{ Jarak Tanam (m) } \\
\hline \multicolumn{2}{|c|}{ Monokultur } & \multicolumn{2}{|c|}{ Polikultur } \\
\hline Kelapa Sawit & Karet & $\begin{array}{l}\text { Kelapa sawit } \mathrm{x} \\
\text { kelapa sawit }\end{array}$ & Kelapa sawit x karet \\
\hline $9 \times 8$ & $4 \times 6$ & $8 \times 8$ & $4 \times 8$ \\
\hline
\end{tabular}

Berdasarkan Tabel 2, dapat dijelaskan bahwa rata-rata jarak antar kelapa sawit pada sistem polikultur adalah 8 x 8m dengan jumlah populasi 144 batang/ha, sedangkan ratarata jarak antar tanaman tidak seragam, namun secara umum rata-rata jarak tanam 4 x 8 $\mathrm{m}$ dengan jumlah populasi $300 \mathrm{batang} / \mathrm{ha}$. Pada sisitem monokultur rata-rata jarak tanam antar kelapa sawit 9 × $8 \mathrm{~m}$ dengan jumlah populasi 132 batang/ha, sedangkan rata-rata jarak tanam tanaman karet 4 × 6 m dengan jumlah populasi 400 batang/ha

Tinggi Tanaman

Hasil pengukuran tinggi tanaman kelapa sawit dan tanaman karet (Lampiran 3) pada penanaman kombinasi, serta tinggi tanaman karet dan kelapa sawit pada penanaman tunggal dapat dilihat pada Tabel 3 .

Tabel 3. Tinggi tanaman kelapa sawit dan karet pada sistem monokultur dan sistem polikultur.

\begin{tabular}{lll}
\hline & \multicolumn{2}{c}{ Tinggi Batang $(\mathrm{m})$} \\
\hline Tanaman & Monokultur & Polikultur \\
Kelapa sawit & 7,43 & 8,12 \\
Karet & 16,38 & 16,28 \\
\hline
\end{tabular}

Tabel 3 menunjukkan bahwa tinggi tanaman kelapa sawit pada sistem polikultur lebih tinggi dari pada sistem monokultur, sedangkan tinggi tanaman karet pada sistem monokultur lebih tinggi dari sistem polikultur.

\section{Lingkar Batang}

Berdasarkan hasil pengukuran, lingkar batang tanaman kelapa sawit dan tanaman karet (Lampiran 4) pada sistem monokultur dan polikultur terdapat perbedaan rata-rata lingkar batang. Perbedaan tersebut dapat dilihat pada Tabel 4. 
Jurnal Media Pertanian Vol. 1 No. 2 Tahun 2016 Hal. 69 - 77

Media Komunikasi Hasil Penelitian dan Review Literatur Bidang Ilmu Agronomi ISSN $2503-1279$

Tabel 4. Lingkar batang kelapa sawit dan tanaman karet pada sistem monokultur dan sistem polikultur

\begin{tabular}{lll}
\hline \multicolumn{2}{c}{ Lingkar Batang $(\mathrm{m})$} \\
\hline Tanaman & Monokultur & Polikultur \\
Kelapa sawit & 3,04 & 2,71 \\
Karet & 0,7 & 0,68 \\
\hline
\end{tabular}

Dari Tabel 4, dapat dilihat bahwa rata-rata lingkar batang kelapa sawit dan tanaman karet pada sistem monokultur lebih besar dibandingkan dengan lingkar batang tanaman kelapa sawit dan tanaman karet pada sistem polikultur.

\section{Panjang Pelepah Kelapa Sawit}

Berdasarkan hasil pengukuran, rata-rata panjang pelepah kelapa sawit terdapat perbedaan antara kelapa sawit pada sistem monokultur dibandingkan dengan sistem polikultur, perbedaan panjang pelepah tersebut dapat dilihat pada Tabel 5.

Tabel 5. Panjang pelepah kelapa sawit sistem monokultur dan sistem polikultur

\begin{tabular}{lll}
\hline \multicolumn{2}{c}{ Panjang pelepah (m) } \\
\hline Tanaman & Monokultur & Polikultur \\
Kelapa sawit & 7,38 & 7,65 \\
\hline Dari Tabel 5 dapat dilihat bahwa panjang pelepah kelapa sawit pada sistem polikutur
\end{tabular}

Dari Tabel 5 dapat dilihat bahwa panjang pelepah kelapa sawit pada sistem polikutur lebih panjang dibandingkan dengan sistem monokultur.

\section{Umur Mulai Produksi (tahun)}

Berdasarkan hasil pengamatan dan wawancara dengan petani terdapat perbedaan umur mulai produksi pada tanaman kelapa sawit dan tanaman karet dengan sistem monokultur dan polikultur. Umur mulai produksi kelapa sawit dan tanaman karet dapat dilihat pada Tabel 6.

Tabel 6. Umur mulai berproduksi tanaman kelapa sawit dan tanaman karet pada sistem monokultur dan sistem polikultur

\begin{tabular}{lll}
\hline \multicolumn{2}{l}{ Umur Mulai Produksi (tahun) } \\
\hline Tanaman & Monokultur & Polikultur \\
Kelapa sawit & 5 & 5.5 \\
Karet & 6 & 6
\end{tabular}

Dari Tabel 6, dapat dilihat bahwa umur mulai berproduksi untuk tanaman kelapa sawit sistem monokultur lebih cepat dibandingkan sistem polikultur, sedangkan umur mulai berproduksi tanaman karet sama pada sistem monokultur dan polikultur.

\section{Produksi (Ton/ha)}

Berdasarkan hasil wawancara dengan petani produksi tanaman kelapa sawit dan tanaman karet baik pada sistem monokultur dan sistem polikultur berbeda. Perbedaan produksi tanaman kelapa sawit dan tanaman karet sistem monokultur dan sistem polikultur dapat dilihat pada Tabel 7. 
Jurnal Media Pertanian Vol. 1 No. 2 Tahun 2016 Hal. 69 - 77

Media Komunikasi Hasil Penelitian dan Review Literatur Bidang Ilmu Agronomi ISSN $2503-1279$

Tabel 7. Produksi TBS kelapa sawit dan tanaman karet pada sistem monokultur dan sistem polikultur (ton/ha)

Produksi (Ton/ha)

\begin{tabular}{lll}
\hline Tanaman & Monokultur & Polikultur \\
Kelapa sawit & 1,0 & 0,8 \\
Karet & 0,1 & 0,06 \\
\hline
\end{tabular}

Dari Tabel 7, dapat dilihat bahwa produksi tanaman kelapa sawit sistem monokultur lebih tinggi dibandingkan dengan sistem polikultur, sedangkan produksi tanaman karet sistem monokultur lebih tinggi dibandingkan dengan sistem polikultur.

Dalam budidaya tanaman kelapa sawit dan tanaman karet dengan sistem polikultur menunjukkan produksi lebih rendah dibandingkan dengan sistem monokultur. Dilihat dari pertumbuhannya tanaman kelapa sawit menunjukkan pertumbuhan lingkar batang kecil, tinggi tanaman dan panjang pelepah lebih tinggi, dibanding sistem monokultur. Hal ini terjadi karena pada sistem polikultur populasi tanaman lebih banyak (melebihi populasi optimum) sehingga akan terjadi persaingan dalam hal penyerapan unsur hara dan air dalam tanah. Selain itu tajuk tanaman kelapa sawit dan tajuk tanaman karet saling tindih mengakibatkan persaingan mendapatkan sinar matahari yang dibutuhkan untuk proses fotosintesis. Disamping itu tanaman kelapa sawit membutuhkan cahaya penuh (banyak), pada kondisi kekurangan cahaya pertumbuhan tanaman kelapa sawit akan lebih tinggi.

Sejalan pendapat Ella dan Nurhayu (2010), pada sistem polikultur proses fotosintesis yang tidak maksimal mengakibatkan produktivitas kedua tanaman menjadi rendah. Selain itu akibat dari tumpang tindih kedua tajuk tanaman mengakibatkan terjadi pertumbuhan yang meninggi ( etiolasi ).

\section{Produktivitas Lahan}

Berdasarkan hasil estimasi produksi dapat diketahui produktivitas lahan pada penanaman tumpangsari dihitung dengan menggunakan rumus Nisbah Kesetaraan Lahan (NKL).

$$
\begin{aligned}
& \text { NKL }=\frac{19,2}{24,0}+\frac{7,2}{10,1} \\
& =0.8+0.71 \\
& =1.5
\end{aligned}
$$

Berdasarkan hasil perhitungan rata-rata produktivitas lahan (NKL) tanaman polikultur kelapa sawit dan karet lebih besar dari satu ( NKL >1).

Dari perhitungan nilai kesetaraan lahan diperoleh nilai NKL 1,5. Hal ini menggambarkan sistem polikultur lebih menguntungkan $50 \%$ atau setengah dari sistem monokultur. Nisbah kesetaraan lahan merupakan salah satu cara menghitung produktivitas yang ditanam 2 atau lebih tanaman yang ditumpangsarikan. Sistem tumpangsari akan lebih menguntungkan jika NKL $>1$. Apa bila nilai $\mathrm{NKL}=1$ menunjukkan bahwa pola sistem monokultur dan sistem polikultur memberikan keuntungan yang sama. Sejalan pendapat (Ella dan Nurhayu, 2010) yang menyatakan bahwa nilai rata-rata NKL yang >1 menggambarkan bahwa pertanaman campuran menguntungkan jika ditanam secara tumpangsari dibanding monokultur. 


\section{KESIMPULAN}

1. Produksi tanaman kelapa sawit dan karet pola monokultur lebih besar dari sistem polikultur. Namun berdasarkan penghitungan nilai nisbah kesetaraan lahan (NKL) menunjukkan nilai >1 menggambarkan bahwa sistem polikultur lebih menguntungkan dibandingkan sistem monokultur.

2. Pengamatan di lapangan menunjukkan kelapa sawit dan karet sistem polikultur kerapatannya terlalu sempit dan tidak seragam sehingga terjadi persaingan dalam penggunaan cahaya, air dan unsur hara dalam tanah.

\section{DAFTAR PUSTAKA}

Arsyad, A, 2012. Morpologi Tanaman Kelapa Sawit. Penelitian Universitas Jambi. Jambi.

Dinas Perkebunan Provinsi Jambi, 2012. Statistik Luas Area, Produksi dan Produktivitas Tanaman Perkebunan Provinsi Jambi.

Direktorat Jenderal Perkebunan. 2014. Data Dirjen Perkebunan Kementrian Pertanian Provinsi Di Indonesia.

Edi, W dan Zainal, M. 2003. Tanaman Sela di Antara Pertanaman Kelapa Sawit. (http://peternakan.litbang.pertanian.go.id/fullteks/lokakarya/probklu0318.pdf?secure=1). diakses 17/02/2015

Ella dan Nurhayu. 2010. NKL-Pertanaman Kacang Tanah dan Jagung. Pusat Perpustakaan dan Penyebaran Teknologi Pertanian. Bogor.

Hendroatmodjo, 2009. Teknik Budidaya Tanaman Monokultur dan Tumpangsari. Padjadjaran University Press. Bandung.

Manurung, 2000; Potter and Lee, 1998. Dampak Lingkungan Pembukaan Lahan Kelapa Sawit. (https://adekrawie.wordpress.com/2007/07/27/dampak-ekologi-dan-lingkunganakibat-perkebunan-sawit-skala-besar/). Diakses 17/02/2015 